Cribb, S. J. 1982: The Torsvik sagvandite body, North Norway. Norsk geol. Tidsskr. 62, 161-168.

Noe-Nygaard, A. \& Ramberg, H. 1961: Geological reconnaissance map of the country between latitudes $69^{\circ} \mathrm{N}$ and $63^{\circ} 45$ N, West Greenland. Meddr Grønland 123(5), 9 pp.

Ohnmacht, W. 1974: Petrogenesis of carbonate-orthopyroxenites (sagvandites) and related rocks from Troms, northern Norway. J. Petrology 15, 303-323.

Petersen, O. V. \& Secher, K. 1984: Grönland. Mineralien. Geologie. Geschichte. Magma 6/84, 83 pp. Bochum: Bode \& Partner KG.

Schreyer, W., Ohnmacht, W. \& Mannchen, J. 1972: Carbonate-orthopyroxenites (sagvandites) from Troms, northern Norway. Lithos 5, 345-364.
Secher, K., Nielsen, B. J. \& Knudsen, N. Ø. 1982: Grønlands smykkesten, 52 pp. Copenhagen: Den Kongelige Grønlandske Handel.

Winkler, H. G. F. 1979: Petrogenesis of metamorphic rocks. 5 th ed. 348 pp. Berlin: Springer-Verlag.

M. M., Institut for Almen Geologi, Øster.Voldgade 10, DK-1350 Copenhagen $K$, Denmark.

\title{
Border relations between the amphibolite facies Finnefjeld gneiss complex and granulite facies grey gneisses in the Fiskefjord area, southern West Greenland
}

\author{
Mogens Marker and Adam A. Garde
}

The authors carried out geological mapping in August 1987 at the south-eastern boundary of the Finnefjeld gneiss complex around $65^{\circ} \mathrm{N}$. The field work was supported by the GGU cutter 'J. F. Johnstrup'.

Based on reconnaissance mapping in the 1950 s Berthelsen $(1951,1957,1962)$ divided the Archaean gneiss terrain in the southern Sukkertoppen district between Godthåbsfjord and Søndre Isortoq into three major tectonic units: the Nordland, the Finnefjeld and the Alángua complexes. This division was also followed by Noe-Nygaard \& Ramberg (1961).

The Nordland complex of Berthelsen in the south (fig. 1) consists of mainly basic supracrustal rocks intruded by voluminous $c$. $3000 \mathrm{Ma}$ old grey tonalitic gneisses, referred to as grey gneisses by Garde et al. (1986) and Garde (in press). The supracrustal rocks and orthogneisses show complex polyphase folding and have been metamorphosed under granulite facies conditions and later partially retrograded to amphibolite facies mineral parageneses.

The Finnefjeld complex in the central part of the region mainly consists of homogeneous grey biotite- and hornblende-bearing orthogneisses with amphibolite facies mineral assemblages. Berthelsen (1957, 1962) found occasional relics of hypersthene in the Finnefjeld gneiss complex and suggested that an episode of granulite facies metamorphisn preceded the amphibolite facies episode in the whole complex.

The Alángua complex to the north (fig. 1) consists of pelitic to semipelitic schists and basic supracrustal rocks embedded in homogeneous orthogneisses. The rocks are intensively folded and metamorphosed under highgrade conditions, with garnet and sillimanite in pelitic lithologies.

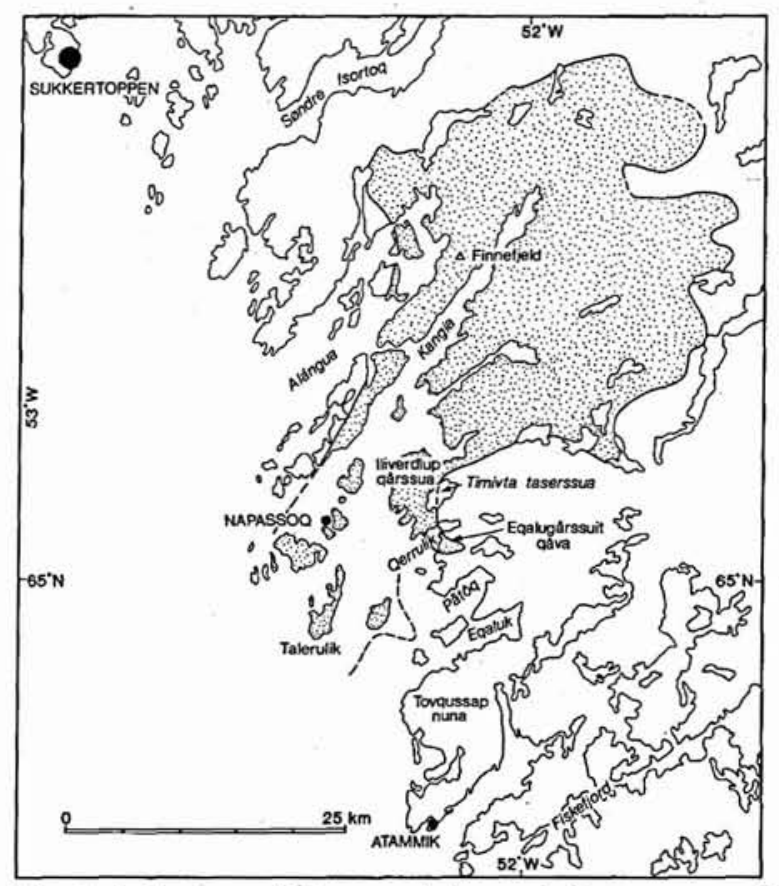

Fig. 1. Index map of the area between Sukkertoppen and Fiskefjord. The extent of the Finnefjeld gneiss complex is shown with dots. 


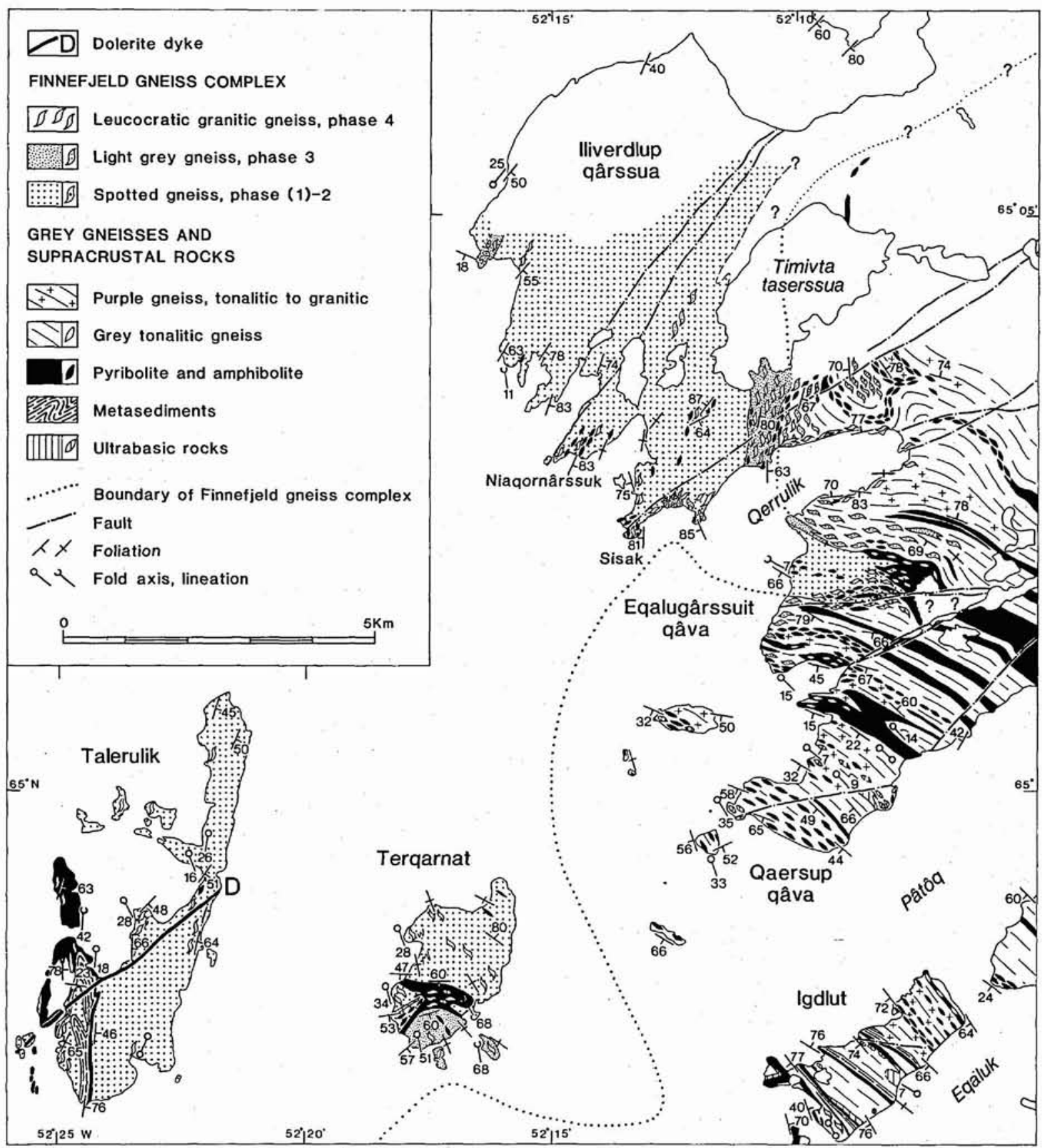

Fig. 2. Geological map of the southern border area of the Finnefjeld gneiss complex.

Berthelsen $(1957,1962)$ concluded that the Finnefjeld gneiss complex represents the retrograded and tectonised northern continuation of his Nordland complex which was thrust over the Alángua complex to the north-west. Berthelsen's investigations concentrated on the north-western part of the Finnefjeld complex, whereas no details of the border relations of its southern part were known until recently.

In connection with the systematic mapping for the Fiskefjord map sheet 64 V.1 N at scale 1:100 000 (Garde \& McGregor, 1982; Garde, 1984, 1986), gneisses belonging to the Finnefjeld complex were re- 
examined in 1986 on the island of Talerulik in the northwestern corner of the map sheet area (Garde et al., 1987). This mapping revealed that the Finnefjeld gneiss complex is composed of at least four successive phases of homogeneous grey biotite (-hornblende) gneisses showing well preserved intrusive relations to each other. Similar polyphase intrusive relations were observed at a few localities on the coast of Iliverdlup qârssua.

The Finnefjeld gneisses show equilibrium amphibolite facies mineral assemblages and clear polyphase intrusive relations, and do not contain retrograde blebby textures (see e.g. McGregor et al., 1986). Therefore the conclusion (Berthelsen, 1957, 1962) that the Finnefjeld gneiss complex represents retrograded gneisses belonging to the northern part of the Nordland complex, i.e. grey gneisses, could not be substantiated.

The boundary between the Finnefjeld gneiss complex and the grey gneisses was not located during reconnaissance mapping in 1986. However, the boundary did not appear to be in the position shown by Berthelsen (1962, Plate 1). Therefore the border area between these two important groups of gneisses was closely examined in 1987, in the light of the observations in 1986. The investigation concentrated on the area between Pâtôq in the south and Iliverdlup qârssua in the north, as well as the island of Talerulik.

\section{Field relations and rock types}

The mapping in 1987 revealed that the boundary between the Finnefjeld gneiss complex and grey gneisses is situated some kilometres further to the south-east (fig. 1) than hitherto believed (cf. Berthelsen, 1962 Plate 1; Allaart, 1982). The Finnefjeld gneisses were everywhere found to be intrusive into the grey Nûk-type gneisses (viz. the Nordland complex of Berthelsen). In the Iliverdlup qârssua area, the boundary curves around the western shore of Timivta taserssua (fig. 2). From the southern point of this lake it runs north-south to Qerrulik before it curves eastwards to Eqalugârssuit qâva, where it ends in an eastward-pointing apex. From the western coast of Eqalugârssuit qâva the boundary curves to the south (fig. 1) and it is inferred that it runs close to the southern tip of the island of Terqarnat (see below).

The best area to study the border relations is around Qerrulik and on Eqalugârssuit qâva. Particularly in the latter area, Finnefjeld gneisses are clearly seen to cut across rocks and structures within the grey gneiss terrain (fig. 2).

The grey gneisses and supracrustal rocks. In the area studied these are similar to those described from elsewhere in the Fiskefjord area (Berthelsen, 1960; Garde \& McGregor, 1982; Garde, 1984, 1986; Garde et al., 1987). The supracrustal rocks mainly consist of mafic, commonly hypersthene-bearing, rocks (pyribolites) with local metasediments, which are intruded by voluminous grey tonalitic gneisses. The gneisses are mainly light grey to grey rocks with retrogressive amphibolite facies parageneses and textures, and occasionally blebby textures visible in the field. Part of the gneisses, particularly around the head of Qerrulik, still contain a granulite facies mineralogy with hypersthene. Tracts of purple coloured gneisses (Berthelsen, 1960) with granodioritic to granitic compositions are widespread on Qaersup qâva and on the two small islands between Qaersup qâva and Terqarnat. It seems to be a general regional feature that purple gneisses are most common in a wide zone up to the north-western boundary of the grey gneisses. This pattern may suggest that it is genetically related to the Finnefjeld gneiss complex.

The Finnefjeld gneiss complex. This is composed of at least four intrusive phases. On the mainland in the Iliverdlup qârssua - Eqalugârssuit qâva area the predominant second phase (corresponding to Finnefjeld gneiss, Berthelsen, 1957, 1962) is a medium-grained homogeneous spotted grey gneiss of intermediate composition, often with feldspar porphyroblasts. In the less strained varieties biotite and/or hornblende occur within irregular 1-4 mm large, evenly distributed spots. The rock is massive and almost unfoliated on Eqalugârssuit qâva and north-west of Qerrulik in the southern part of the Finnefjeld gneiss area. It intrudes both grey tonalitic gneisses and pyribolite in the border zone to the south. At one locality original magmatic banding can still be observed (fig. 3). The strain increases towards the north-west, and northwards from around Niaqornârssuk the spotted, second phase gneiss is gradually transformed into a somewhat more fine-grained, foliated, rather striated rock. About $1 \mathrm{~km}$ east of Sisak the spotted phase is seen to form veins in an even older, dark grey, medium-grained gneiss (Finnefjeld gneiss phase one).

The third phase of Finnefjeld gneiss is a homogeneous, fine- to medium-grained, light grey, leucocratic rock with fine-grained dispersed biotite that forms a weak foliation. This phase, which may contain inclusions of the spotted phase two (fig. 4), seems to occur mainly in the border zone between the spotted (phase 1-2) Finnefjeld gneiss and the grey gneisses to the south (fig. 2). It intrudes the latter in a zone over one kilometre wide which forms a diffuse boundary to the grey gneisses. Their mutual relations are best observed on 


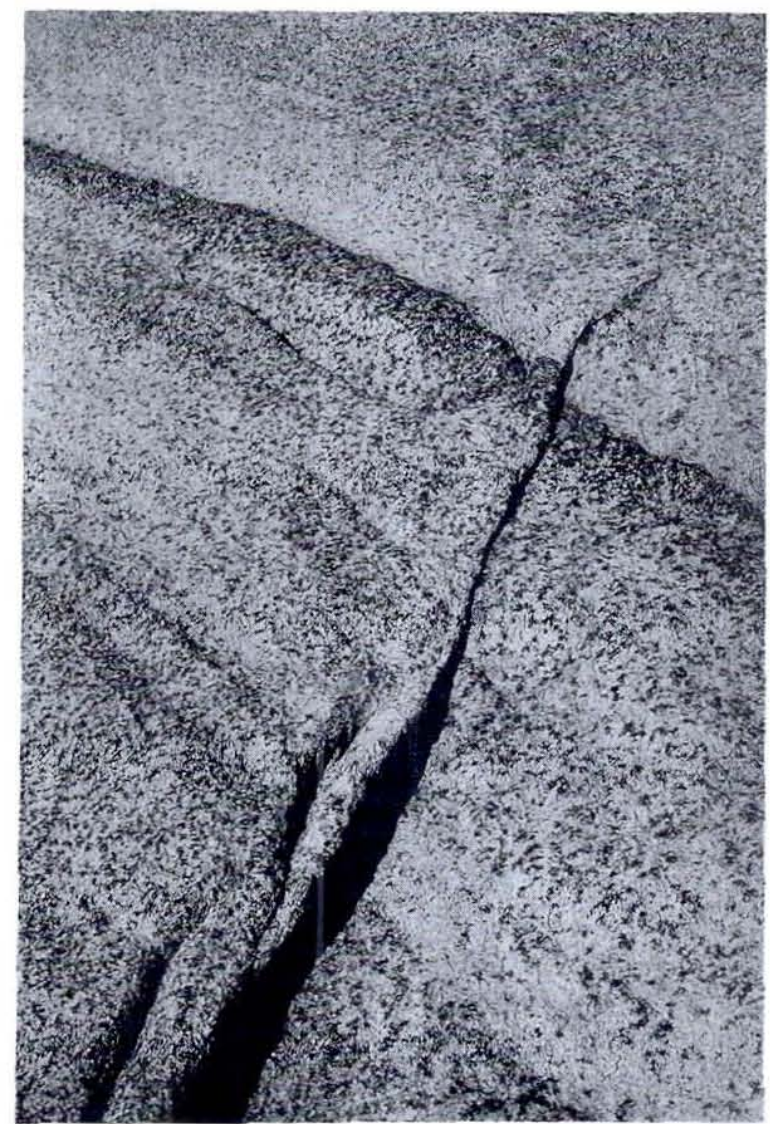

Fig. 3. Compositional layering of presumed magmatic origin in Finnefjeld gneiss phase two; south side of Qerrulik.

clean-washed coastal exposures. The third phase of Finnefjeld gneiss also has a more pronounced foliation towards the north-west.

The fourth phase is a light greyish to white, mediumto rather coarse-grained, leucocratic, biotite gneiss or granite with granitic composition. It has high-angle intrusive contact relations to the earlier phases and to the grey gneisses in the border zone (fig. 2). The fourth phase seems to have been only partially involved in the folding affecting the first three phases of Finnefjeld gneiss, and it is therefore considered to be syntectonic. It has often been intruded parallel to axial surfaces of folds deforming the earlier intrusive phases. Phase four was succeeded by cross-cutting pegmatite dykes which may, however, be closely related to the fourth phase. Grey dykes seen at several localities cut all four intrusive phases of Finnefjeld gneiss.

The Finnefjeld gneisses on Talerulik (fig. 2) are mainly medium to light grey, very homogeneous, highly strained, biotite gneisses. Occasionally feldspar- and biotite-spotted textures like those common in the in-

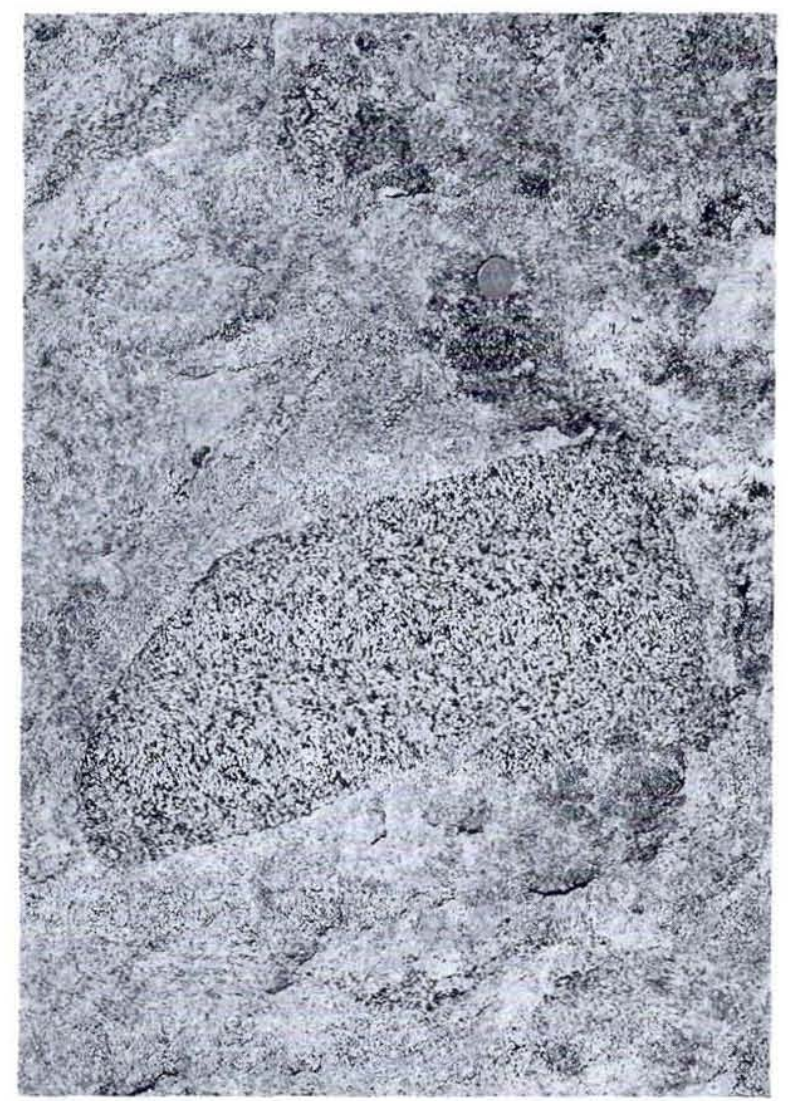

Fig. 4. Inclusion of spotted Finnefjeld gneiss (intrusive phase two) in Finnefjeld gneiss with dispersed biotie (intrusive phase three); c. $800 \mathrm{~m}$ north-east of Sisak.

trusive second phase of the Finnefjeld gneisses on the mainland can be discerned in the least deformed varieties. Cross-cutting and axial surface-parallel white granitic gneisses (intrusive phase four) are particularly common in the south-western part of the island, where large pegmatites also occur.

The island of Terqarnat (fig. 2) is divided by a curved, east-west trending amphibolite/pyribolite unit with an east-facing isoclinal fold. In the northern part of the island easily recognisable biotite (-hornblende) and plagioclase-spotted, amphibolite facies, Finnefjeld gneisses belonging to the first and second phases predominate, but all four intrusive phases are present. The area to the south of the amphibolite and on the two small islands to the south-east are composed of homogeneous, light grey, apparently un-retrograded amphibolite facies gneiss characterised by fine-grained dispersed biotite. This area is tentatively ascribed to the third phase of Finnefjeld gneiss in the border zone, but correlation with other islands and the mainland is uncertain. 


\section{Structural geology}

A coherent structural analysis has not yet been made in the area studied here, or in the grey gneiss terrain further south, but some general statements can be made.

At least the north-western part of the Finnefjeld gneiss complex is highly deformed with high-strain fabrics and tight to isoclinal mesoscopic folds, although the structures are not always clearly mappable due to lack of marker horizons. The axial surfaces generally dip moderately to steeply to the south-east, parallel to the regional foliation. At Iliverdlup qârssua (fig. 2) the fold axes generally plunge south-west, while a few mineral lineations plunge gently to the SSE. At Talerulik most fold axes plunge gently to the south. At Terqarnat the plunge of folds is generally to the south-east and a strong NW-SE striking cleavage parallel to the axial surfaces is present. These folds everywhere affect the first three intrusive phases of Finnefjeld gneiss, and in part the fourth. The leucocratic fourth phase is often intruded as veins parallel to the axial surfaces, and folded veins of the fourth phase often show preferred orientations of their dark minerals (biotite, hornblende, garnet) in the same direction.

In the western part of Talerulik a large north-south trending unit of metasediments and (hypersthene-bearing) pyribolites, perhaps originally part of the Alángua complex, occurs adjacent to Finnefjeld gneiss. The supracrustal rocks were already folded before the intrusion of the Finnefjeld gneiss protoliths. During subsequent folding of both units, the supracrustal rocks were refolded into tight to isoclinal folds with subhorizontal north-south trending fold axes and steep eastdipping axial surfaces. The refolding was accompanied by recrystallisation and incipient anatexis in the metasediments under amphibolite facies conditions (Garde et al., 1987). The synkinematic fourth phase of Finnefjeld gneiss intrudes the supracrustal rocks as well as the earlier phases of Finnefjeld gneiss.

Unfortunately the southern and western boundaries of the Finnefjeld gneiss complex are hidden beneath the sea. Along its south-eastern margin the Finnefjeld gneiss intrudes large-scale fold structures in the grey gneiss-pyribolite terrain between Qerrulik and Pâtôq (fig. 2). These folds in the grey gneiss terrain have horizontal to gentle SE-plunging axes and SW-dipping axial surfaces. The axial directions and the structural style suggest that these folds are equivalent to the Pâkitsoq fold phase on Tovqussap nunâ (Berthelsen, 1960, 1962), which took place under granulite facies conditions. If this correlation is correct, the intrusion of the Finnefjeld gneisses took place after the last main epi- sode of folding in the grey gneisses (the Pâkitsoq fold phase). The possibility remains, however, that the folds in the grey gneisses between Qerrulik and Pâtôq are reorientated folds formed at an earlier stage than the Pâkitsoq phase, perhaps during the Smalledal fold phase of Berthelsen (1960). At present we prefer the former correlation; a safer conclusion may be reached when the fold interference patterns in the grey gneisses in the Fiskefjord area have been analysed.

\section{Discussion and conclusions}

Mapping of the Finnefjeld gneiss complex and the grey gneisses along its southern boundary does not support the conclusion (Berthelsen, 1957, 1962) that the former was reworked from the latter during retrograde metamorphism and tectonisation. That conclusion was influenced by the then topical 'granitisation theory' (A. Berthelsen, personal communication, 1987). Instead, we interpret the Finnefjeld gneiss complex as a batholith complex that intruded the grey gneiss-pyribolite terrain. The intrusion appears to have caused quite extensive remobilisation of the country rocks, giving rise to a hybrid border zone and back-veining of granitic material into the early phases of the Finnefjeld gneisses.

Mineral assemblages and rock textures strongly suggest that the Finnefjeld gneisses themselves never reached granulite facies conditions, although the Finnefjeld gneiss complex may contain older gneiss enclaves with a more complex metamorphic history. Berthelsen (1962) described some small patches with a dark variety of Finnefjeld gneiss that contain relic hypersthene close to the boundary to the Alángua complex. These patches may well represent partially digested xenoliths derived from the southern part of the Alángua complex, where hypersthene-bearing gneisses are known to occur (Berthelsen, 1962). Alternatively they may reflect local dry patches within the batholith (A. Berthelsen, personal communication, 1987).

It is evident from the new field work that the Finnefjeld gneisses intrude into earlier fold structures in the grey gneisses and supracrustal rocks. This may also be inferred from the 1:500 000 geological map Frederikshåb Isblink - Søndre Strømfjord (Allaart, 1982) which shows that large-scale structures in the grey gneisses terminate against the Finnefjeld gneiss. It is likely that the NW-SE orientated Pâkitsoq fold phase, which took place under granulite facies conditions in the grey gneisses, predates intrusion of the Finnefjeld gneiss protoliths. Folding of the Finnefjeld gneisses is possibly equivalent to the 'Posthumous phase' in Berthelsen's Nordland complex.

The following evolutional history for the Finnefjeld 
gneiss is proposed from our investigation. After the main deformation, granulite facies metamorphism and possibly retrogression of the grey gneiss terrain, the protoliths to the Finnefjeld gneisses were intruded as a polyphase batholithic complex. The earlier and more voluminous first and notably second Finnefjeld gneiss phases caused remobilisation of the country rock, giving rise to a hybrid border zone and back-veining into the early phases of the Finnefjeld gneiss complex. The light grey, dispersed biotite-bearing Finnefjeld gneiss (the third intrusive phase), which preferably occurs along the contact zone adjacent to the grey gneisses (fig. 2), seems to have formed during the remobilisation. The Finnefjeld gneiss complex was then deformed under amphibolite facies conditions in a NW-SE orientated stress field, during which folding and local overthrusting to the north-west took place (cf. Berthelsen, 1957, 1962). At the same time syntectonic granitic veins and minor bodies of the fourth Finnefjeld gneiss phase were intruded.

In several ways the Finnefjeld gneiss complex resembles the Taserssuaq tonalite some $75 \mathrm{~km}$ to the south-east (see Garde et al., 1983, 1986; Nutman \& Garde, in press). Both are large, polyphase, homogeneous batholithic masses of predominantly tonalitic gneisses with locally preserved igneous layering, which have intruded into already folded and metamorphosed supracrustal rocks and middle Archaean grey gneisses.

Acknowledgements. We thank A. Berthelsen, Geological Institute, University of Copenhagen, and F. Kalsbeek, GGU, for discussions and comments.

\section{References}

Allaart, J. H. (compiler) 1982: Geologisk kort over Grønland, 1:500 000, Sheet 2, Frederikshåb Isblink - Søndre Strømfjord. Copenhagen: Geol. Surv. Greenland.

Berthelsen, A. 1951: A Pre-Cambrian dome structure at Tovqussaq, West-Greenland. Meddr dansk geol. Foren. 11, 558572.

Berthelsen, A. 1957: The structural evolution of an ultra- and polymetamorphic gneiss complex, West Greenland. Geol. Rdsch. 46, 173-185.

Berthelsen, A. 1960: Structural studies in the pre-Cambrian of western Greenland; part II: Geology of-Tovqussap nunâ. Meddr Grønland 123(1) (also Bull. Grønlands geol. Unders. 25), 223 pp.
Berthelsen, A. 1962: Structural studies in the pre-Cambrian of western Greenland; part III: Southern Sukkertoppen district. Meddr Grønland 123(2) (also Bull. Grønlands geol. Unders. 31), 47 pp.

Garde, A. A. 1984: Field work between Fiskefjord and Godthåbsfjord, southern West Greenland. Rapp. Grønlands geol. Unders. 120, 45-50.

Garde, A. A. 1986: Field observations around northern Godthåbsfjord, southern West Greenland. Rapp. Grønlands geol. Unders. 130, 63-68.

Garde, A. A. in press: Retrogression and fluid movement across a granulite-amphibolite facies boundary in middle Archaean Nûk gneisses, Fiskefjord, southern West Greenland. In Bridgwater, D. (edit.) Fluid movements, element transport, and the composition of the deep crust. Dordrecht: Reidel.

Garde, A. A. \& McGregor, V. R. 1982: Mapping in the Fiskefjord area, southern West Greenland. Rapp. Grønlands geol. Unders. 110, 55-57.

Garde, A. A., Hall, R. P., Hughes, D. J., Jensen, S. B., Nutman, A. P. \& Stecher, O. 1983: Mapping of the Isukasia sheet, southern West Greenland. Rapp. Grønlands geol. Unders. 115, 20-29.

Garde, A. A., Larsen, O. \& Nutman, A. P. 1986: Dating of late Archaean crustal mobilisation north of Qugssuk, Godthåbsfjord, southern West Greenland. Rapp. Gronlands geol. Unders. 128, 23-36.

Garde, A. A., Jensen, S. B. J. \& Marker, M. 1987: Field work in 1986 in the Fiskefjord area, southern West Greenland. Rapp. Grønlands geol. Unders. 135, 36-42.

McGregor, V. R., Nutman, A. P. \& Friend, C. R. L. 1986: The Archaean geology of the Godthåbsfjord region, southern West Greenland. In Ashwal, L. D. (edit.) Workshop early crustal genesis: the world's oldest rocks. Tech. Rep. Lunar Planet. Inst. 86-4, 113-164.

Noe-Nygaard, A. \& Ramberg, H. 1961: Geological reconnaissance map of the country between latitudes $69^{\circ} \mathrm{N}$ and $63^{\circ} 45$ N, West Greenland. Meddr Grønland 123(5), 9 pp.

Nutman, A. P. \& Garde, A. A. in press: The role of fluid in the accretion of Archaean sial. In Bridgwater, D. (edit.) Fluid movements, element transport, and the composition of the deep crust. Dordrecht: Reidel. 